Article

\title{
Impact of Sustainability on Firm Value and Financial Performance in the Air Transport Industry
}

\author{
Yaghoub Abdi * (1), Xiaoni Li and Xavier Càmara-Turull(1) \\ Department of Business Management, Faculty of Business and Economics, Universitat Rovira i Virgili, \\ 43204 Reus, Tarragona, Spain; xiaoni.li@urv.cat (X.L.); xavier.camara@urv.cat (X.C.-T.) \\ * Correspondence: yaghoub.abdi@urv.cat; Tel.: +34-644-54-19-82
}

Received: 12 August 2020; Accepted: 22 November 2020; Published: 28 November 2020

\begin{abstract}
In this study, we examine the extent to which the implementation of environmental, social, and governance (ESG) disclosures influence the firm value and financial performance of airlines. The panel data analysis is applied to the set of collected data from the Thomson Reuters Eikon database for the sample of 27 airlines worldwide from 2013 to 2019. Findings of this study support the positive relationship between the environmental pillar score (Env) and governance pillar score (Gov), with market-to-book ratio and Tobin's $Q$ as proxies for firm value and financial performance, respectively. This finding implies that an increase in both pillars leads to higher market value and financial efficiency for investigated airlines. Therefore, an airline's effort to improve Env and Gov dimensions will lead to higher market value and return on invested funds. In contrast, the social pillar disclosure in both models is found to have a significant negative association with the dependent variables, showing that airlines' social activities result in lower value as well as level of performance.
\end{abstract}

Keywords: sustainability; firm value; financial performance; air transport industry; environmental, social and governance (ESG); market-to-book ratio; Tobin's Q

\section{Introduction}

Air transport is considered one of the most popular, rapidly growing industries, offering a broad range of services and community benefits. It provides a service to every country in the world and has played an integral role in the creation of a global economy. The industry is a major economic force, in terms of both operations and impacts on related industries, such as aircraft manufacturing and tourism [1]. Consequently, air transportation has attracted attention not only from people directly involved in the business, but also from financial and industrial experts. However, the airline sector is also regarded as a challenging industry in terms of its environmental impacts and contribution to global climate change, basically through burning fossil fuels and releasing pollutant gases into the atmosphere. Aircraft generate carbon dioxide $\left(\mathrm{CO}_{2}\right)$, which is the main greenhouse gas that directly discharges into the air. According to an air transport action group report, worldwide flights emitted around 915 million tons of $\mathrm{CO}_{2}$ in 2019, which is roughly $2 \%$ of man-made carbon emissions [2]. Recently, as awareness of corporate responsibility and business ethics have increased, the development of long-term strategies and investments to achieve a sustainable industry have been key to guaranteeing the future of air cargo [3]. Both investors and consumers are also attracted by the role of environmental and social issues, as they increasingly support and empower businesses with regards to keeping shares and products more sustainable. Therefore, airlines are aligning themselves by integrating socially responsible aspects into their business practices for the purpose of sustainable development and competition [4].

Environmental, social, and governance (ESG) scores have appeared as an important pillar of corporate social responsibility (CSR) for the development of sustainable strategies that affect the financial performance of multinational firms [5,6]. Firms are interested in about finding out finding out whether 
promoting environmental, societal, and managerial initiatives can also lead to beneficial economic outcomes for the related business. The possibility of financial impetus along with a long-term healthy financial and organizational structure, as well as a favorable public image, are sufficient to motivate companies to move forward on achieving sustainability. Especially, the beginning of the financial crisis in 2008 led to a positive shift in capital market attitudes toward corporate sustainability [7]. It seems that investors in general terms are sensitized to how a firm deals with its responsibility towards this key stakeholder, putting a higher value on companies that are seen to be more concerned about their relations with this corporate sustainability stakeholder [8]. The issue is even more complicated for companies operating in the tourism and hospitality industry. Most recently, reference [9] finds that due to the characteristic intrinsic to the hospitality industry, the financial performance of hospitality firms is more sensitive to addition or deletion events, when compared with the performance of non-hospitality firms. Having the exact estimation of fluctuation in value and financial performance offers a deeper insight for the tourism-related companies to assess their vulnerability in unexpected scenarios such as the current turbulent time of COVID-19, in which companies have faced a rapid decline in performance and share prices [10].

There has been an active debate questioning the financial relevancy of sustainability initiatives proposing theoretical and empirical approaches to deal with the topic. Despite the development of research in the tourism literature, the consequences of implementing sustainability measures is still controversial and scant $[5,11]$. Associated studies use corporate social responsibility (CSR) and ESG (in some studies both have been used interchangeably (e.g., [12]) as representative of sustainability performance as well as Tobin's Q as a financial performance measure. Some suggest that ESG practices have a positive impact on a firm's performance $[13,14]$. However, some studies conclude that a firm's financial performance is negatively impacted by ESGs [15].

In an attempt to enrich the tourism and sustainability literature, the current study investigates the firm's value and sustainability performance for a sample of airlines. We address the impact of environmental, social, and governance (ESG) disclosures in three aspects: first, in what is likely to be the first study, we separately study the ESG components to find out if a firm's ESG disclosures play a significant role in promoting the gap between market-to-book value as a sign of financial distress. Second, we check whether the airlines' financial performance is changed by disclosure of these sustainability practices. In prior studies (e.g., [16,17] among others), return on assets (ROA) was considered the current financial performance of the firms, while in this research we specifically concentrate on airlines' value, along with Tobin's $Q$, as the measure for financial performance. Market-to-book ratio and Tobin's Q provide a good tool of comparison as they take into account the market value of firms [18]. Third, we also define a dummy of airline types, i.e., full-service and low-cost carriers, to test whether these two sub-sets need to be investigated separately. The review of the contemporary research in the air transport domain highlights the importance of conducting this type of study, especially the importance of empirical studies, when trying to understand the evolving literature and its links to financial performance.

The paper proceeds as follows. Section 2 reviews the relevant literature and presents the main hypotheses that we test. Section 3 details the data and sample selection, study variables, and model specification. Section 4 presents the empirical findings. Section 5 discusses the results and, finally, Section 6 provides the study implications, limitations, and some suggestions for future research.

\section{Literature Review}

\subsection{A Review of Sustainability Research}

We begin our review with a brief discussion on the evolution of sustainability. Sustainability is an ambiguous concept, with no single definition to refer to its goals, dimensions, and implications $[19,20]$. There is also no single representative index and reporting framework for the concept, as a set of qualitative and quantitative indices have been developed to measure the state of sustainability of 
the business unit [21], and it is hard to assess the impact of these standards on policy making and moving forward sustainability [22]. The concept was first applied in forestry as a policy, indicating that harvesting has to be less than forest yield in new growth $[23,24]$. It was introduced as a technique of how to deal with natural resources to avoid extinction and preserve them for future generations. The issue was formulated in today's form by the World Commission on Environment and Development (WCED) report known as "Our Common Future" or the "Brundtland Report" in 1987. The report demonstrates the way in which human survival and well-being could depend on successes in raising sustainable development to a global ethic by calling for international awareness and action in respect of population, food, plant and animal species, energy, industry, and urban settlements [25]. It also provides the first comprehensive definition of the sustainable development agenda as "meet the needs of the present without compromising the ability of future generations to meet their own needs". In this context, firms and industries represent a big catalyst for change by paying serious attention to sustainability issues. It is said that emphasis on sustainability assists companies to better manage their social and environmental impacts as well as improve their operational efficiency and natural resource stewardship, which are a vital element in their relations with shareholders, employees, and other stakeholders [26]. From this perspective, the Global Sustainability Standards Board [27] sought ways to place global development on a sustainable path and set up a sustainability reporting framework (promoted by global reporting initiative (GRI) standards) as a practice to assess the economic, environmental, and social contributions of a firm [28]. Presented as triple bottom line reporting, the GRI program provides tools to evaluate the ethical basis of an organization's corporate social responsibility (CSR) sustainability programs, where in this framework companies are required to report results of stakeholder engagement in five economic, environmental, social, society, and product responsibility performance indicators [29].

On this basis, CSR became widely used to address the actions that firms are asked to take from a sustainability perspective. The term was first formalized in reference [30] as a set of obligations to pursue politics or to follow lines of action in decision-making which are desirable in terms of objectives and values of society. In other words, CSR is a voluntary corporate commitment to exceed the explicit and implicit obligations imposed on a company, based on society's expectations of conventional corporate behavior [31]. This means that companies are required to contribute to sustainable development by developing corporate strategies that integrate sustainable practices into their activities with the aim of achieving corporate sustainability [7]. This corporate sustainability by itself is defined as corporate activities that proactively seek to assist sustainability equilibria, including the economic, environmental, and social dimensions over time. It also addresses the company's operations and productions, management and strategy, organizational units, marketing, and communications with its stakeholders [7,32].

Another interesting aspect is that there seems to be a high tendency for investors to be informed about a firm's sustainability performance. Thereby, they become interested in sustainability issues and firms' environmental footprints in their investment decisions. Investors are keen to follow the degree to which firms exhibit a sense of social responsibility and their corporate governance. Specifically, this trend became popular after the United Nations introduced the principles for responsible investment (PRI) program for organizations and researchers interested in sustainability issues in 2005. The goal of the program is for investors to consider and implement responsible environmental, social, and governance factors in their investments in stocks, fixed income, private equity, hedge funds, and real assets [33]. The PRI has developed an initiative, a signatory-based system where participants can access guides, data, reporting and assessment tools to evaluate their progress in sustainability dimensions. So far, it has been signed by 2000 investment managers with $\$ 80$ trillion in assets under management [33]. These standards have been formulated in three areas, jointly captured by the most recent sustainability acronym, ESG [34]. ESG disclosure includes a variety of issues associated with the environment (e.g., climate change), social responsibility (e.g., human rights), and corporate governance (e.g., shareholder protection) [35]. It refers to the three central factors in measuring the sustainability impact of an investment in a company, which makes it possible for a firm to participate in individual 
environmental, social, and government activities at different levels $[6,36]$. The term has been studied well in the literature to investigate financial decisions associated with its involvement. This domain has covered a wide variety of topics such as effects on information asymmetry, cost of capital, and capital structure of firms [37].

\subsection{Sustainability in Air Transport Industry}

The airline industry is a major economic force in terms of its operations and impacts on related businesses, such as aircraft manufacturing and tourism [1]. Moreover, it also has considerable environmental impacts on the global context [38]. The good news is that achieving sustainability in the context of air transport can be done, although it will have costs [39]. Although very slowly, airlines (along with all industries) started to launch environmental, social, and governance initiatives, collectively known as ESG factors, and to report their performance [40]. The ESG factor forms a new accountability measure reflecting a voluntary commitment to non-financial goals [41]. However, the air transport industry's participation in ESG activities is still low [17,42,43]. Recently, it has been seen that $38 \%$ of the top 100 airlines publish a corporate sustainability report, including six airlines that integrate their presentation of corporate sustainability reporting in their overall annual report, and three airlines that publish an environmental report [44]. This participation rate has motivated academicians in the tourism field to investigate the consequences of implementing these initiatives for firms' operations. The trend is more evident as more tourism researchers have shown a growing interest in sustainability performance $[16,45]$. This scholarly attention has been paid to measuring the association between ESG practices and the financial performance of firms providing products and services in the tourism industry. References $[16,46,47]$ are just a sample of these studies investigating the impact of ESG disclosures on the financial performance of airlines, hotels, restaurants, and casinos.

It is shown that while ESG activities may decrease the short-term financial performance of airlines, they can cause significant positive effects on the overall financial performance of air carriers $[16,17,48]$. We summarized the scholarly research conducted and models used regarding sustainability issues in the aviation context. As can be seen from Table 1, these studies have been found through searching Scopus, Web of Science, and Google Scholar and reviewed by theme and methodology used. Based on the results, we see that the existing research could be divided into two main classes: conceptual research and empirical research. With respect to air transport and the tourism industry in general, as also pointed out by references $[49,50]$, studies associated with the sustainability issues are largely conceptual and explanatory. In these contributions, essential aspects of CSR have been recognized in order to be incorporated into the firm's strategy and practices. In one of the most recent works [50], the author argues the new contemporary issue related to the COVID-19 pandemic and adopting challenges to develop these sustainability initiatives at the firm-level. The review also indicates that the empirical studies that have been carried out in the context have been sparse. As for the empirical class, studies have been trying to discuss the linkage between sustainability issues with financial performance. Considering the inadequacy of empirical investigations as an apparent need, our study contributes to filling the gap and bring new insights by offering the broader framework to link the disclosure of ESG pillars separately with subsequent market valuation and financial performance which, especially for the former, we did not find in any existing study.

Table 1. Summary of the scholarly conducted research and models used regarding sustainability performance in the aviation context.

\begin{tabular}{|c|c|c|c|c|}
\hline Author & Title & Journal & Methodology & Key Findings \\
\hline$[51]$ & $\begin{array}{l}\text { Corporate Social } \\
\text { Responsibility (CSR) } \\
\text { among EU low-fares } \\
\text { airlines }\end{array}$ & $\begin{array}{c}\text { Journal of } \\
\text { Sustainable Tourism }\end{array}$ & Content analysis & $\begin{array}{l}\text { There are more CSR activities than are } \\
\text { made public and very few low-fare } \\
\text { airlines had conducted a systemic audit } \\
\text { of CSR-related activities. }\end{array}$ \\
\hline
\end{tabular}


Table 1. Cont.

\begin{tabular}{|c|c|c|c|c|}
\hline Author & Title & Journal & Methodology & Key Findings \\
\hline$[43]$ & $\begin{array}{l}\text { CSR and cost } \\
\text { assessment in the } \\
\text { airline industry }\end{array}$ & $\begin{array}{l}\text { Journal of Air } \\
\text { Transport } \\
\text { Management }\end{array}$ & $\begin{array}{l}\text { A hybrid model to } \\
\text { select optimal aviation } \\
\text { CSR programs and the } \\
\text { costs of those programs }\end{array}$ & $\begin{array}{l}\text { This study offers a hybrid model to help } \\
\text { the airline industry solve the problem } \\
\text { of selection decisions and cost } \\
\text { evaluations of CSR programs. }\end{array}$ \\
\hline [52] & $\begin{array}{l}\text { Evaluating CSR of } \\
\text { airlines }\end{array}$ & $\begin{array}{l}\text { Journal of Air } \\
\text { Transport } \\
\text { Management }\end{array}$ & $\begin{array}{l}\text { Entropy weight and } \\
\text { grey relation analysis }\end{array}$ & $\begin{array}{l}\text { The finding is twofold. First, on-time } \\
\text { performance, accident rate, flight } \\
\text { frequency, growth of employees' } \\
\text { revenue, and employees' revenue are } \\
\text { relatively most important measures of } \\
\text { CSR in eight major Chinese airlines. } \\
\text { Second, most of the larger } \\
\text { state-controlled airlines perform better } \\
\text { in CSR measures. }\end{array}$ \\
\hline [42] & $\begin{array}{l}\text { Synergy of CSR and } \\
\text { service quality among } \\
\text { airlines }\end{array}$ & $\begin{array}{l}\text { Journal of Air } \\
\text { Transport } \\
\text { Management }\end{array}$ & Panel data & $\begin{array}{l}\text { A positive synergistic effect of service } \\
\text { quality and CSR for full services, as well } \\
\text { as a negative synergistic effect of service } \\
\text { quality and CSR for low-cost airlines. }\end{array}$ \\
\hline [53] & $\begin{array}{l}\text { Evaluating technical } \\
\text { and environmental } \\
\text { performance of airlines }\end{array}$ & Economic Modelling & $\begin{array}{c}\text { Data envelopment } \\
\text { analysis (DEA) }\end{array}$ & $\begin{array}{l}\text { Technically efficient airlines are from } \\
\text { China and North Asia, while many of } \\
\text { the best environmental performers are } \\
\text { from Europe. }\end{array}$ \\
\hline$[16]$ & $\begin{array}{l}\text { CSR and firm } \\
\text { performance in the } \\
\text { airline industry with } \\
\text { control for moderating } \\
\text { role of oil prices }\end{array}$ & $\begin{array}{c}\text { Tourism } \\
\text { Management }\end{array}$ & Panel data & $\begin{array}{l}\text { Findings support a positive main effect } \\
\text { from operation-related (OR) CSR } \\
\text { activities on firm performance. In } \\
\text { addition, a positive moderating effect of } \\
\text { oil prices on the relationship between } \\
\text { OR-CSR dimensions has been } \\
\text { confirmed. }\end{array}$ \\
\hline [54] & $\begin{array}{c}\text { Stakeholder } \\
\text { Engagement: A } \\
\text { mechanism for } \\
\text { Sustainable Aviation }\end{array}$ & $\begin{array}{l}\text { Corporate Social } \\
\text { Responsibility and } \\
\text { Environmental } \\
\text { Management }\end{array}$ & Conceptual & $\begin{array}{l}\text { The study provides a stakeholder } \\
\text { engagement framework to support } \\
\text { airport companies in formulating and } \\
\text { implementing strategies for sustainable } \\
\text { airport development and suggests a } \\
\text { practice guide to operationalize the } \\
\text { framework. }\end{array}$ \\
\hline$[55]$ & $\begin{array}{l}\text { Exploring the green } \\
\text { image of airlines: } \\
\text { Passenger perceptions } \\
\text { and airline choice }\end{array}$ & $\begin{array}{l}\text { Journal of Air } \\
\text { Transport } \\
\text { Management }\end{array}$ & $\begin{array}{c}\text { Questionnaire } \\
\text { quantitative method }\end{array}$ & $\begin{array}{l}\text { The green image of airlines does } \\
\text { influence airline choice during booking. } \\
\text { It has been also observed that a } \\
\text { passenger is willing to pay extra for a } \\
\text { green image, however, it is not as much } \\
\text { as their willingness to pay extra for } \\
\text { amenities, such as additional legroom. }\end{array}$ \\
\hline$[48]$ & $\begin{array}{l}\text { Financial impact of } \\
\text { CSR on Airlines }\end{array}$ & $\begin{array}{l}\text { Journal of } \\
\text { Hospitality and } \\
\text { Tourism Research }\end{array}$ & $\begin{array}{l}\text { Multiple regression } \\
\text { analysis }\end{array}$ & $\begin{array}{l}\text { Results support a positive and linear } \\
\text { impact of CSR on value performance } \\
\text { but not on accounting performance for } \\
\text { airline companies. }\end{array}$ \\
\hline$[17]$ & $\begin{array}{l}\text { CSR and financial } \\
\text { performance }\end{array}$ & $\begin{array}{c}\text { Finance Research } \\
\text { Letters }\end{array}$ & Panel data & $\begin{array}{l}\text { CSR increases current and expected } \\
\text { financial performance of both } \\
\text { full-service and low-cost airlines. }\end{array}$ \\
\hline [50] & $\begin{array}{l}\text { New challenges of } \\
\text { environmental } \\
\text { sustainability of global } \\
\text { airline industry due to } \\
\text { Covid-19 }\end{array}$ & Cleaner Production & Conceptual & $\begin{array}{l}\text { Some airlines are sought to sidestep } \\
\text { environmentally friendly commitments } \\
\text { to overcome new challenges such as } \\
\text { cost pressure and survival threat. }\end{array}$ \\
\hline
\end{tabular}

Source: Compiled by authors based on scholarly search in Scopus, Web of Science (WOS), and Google Scholar.

\subsection{Hypothesis Development}

There are three major strands of research regarding corporate sustainability and firm value: the resource-based view, the legitimacy theory, and the stakeholder theory [56]. First, the resource-based view of the company is seen as the firm's competitive advantage tools. These resources are any assets that a firm employs which help it to achieve goals or record the best performance in its key success 
factors [ 57,58$]$. From this perspective, a firm's sources of competitive advantages are a set of tangible and intangible basic resources that come together coherently to enable the organization to attain its goals [58]. In a rational market, ESG pillar score disclosure may bring firms a competitive advantage $[11,59,60]$. Second, according to the legitimacy theory, it is not possible to separate society, politics, and economics. This means that the political, social, and institutional frameworks have to be considered in economic activities [61]. The idea is comprehensively defined by reference [62] as "a generalized perception or assumption that the actions of an entity are desirable, proper, or appropriate within some socially constructed system of norms, values, beliefs, and definitions". On this basis, if shareholders perceive that a firm's performance is not sustainable, the company's legitimacy is under threat and risky for the long-term survival of the firm [63]. This implies that the company's ability to do business depends on the public image in society. As most investors are unable to individually assess the sustainability of a firm, they rely on ESG pillar scores as an indicator of its legitimacy and ethical business practices provided by sustainability rating agencies [64]. Thus, participation in ESG activities could be a tool by means of which a firm can gain social legitimacy for environmental, social, and governance impacts of its operations. Third, the stakeholder theory focuses on the relationship between a firm and all bodies involved in its business domain, including customers, investors, community, etc. Reference [65] defined the concept as all those who can affect, or are affected by, the achievement of organizational objectives. Based on this theory, an organization has to work to satisfy its stakeholders. If it manages to successfully meet the demands of its stakeholders, organizational sustainability will be achieved. Therefore, as reference [66] noted, "Global sustainability will be promoted if organizational sustainability is achieved without compromising the ability of interested parties to meet their needs, both present and future".

Building on this research background, in this study, the aim was to test whether a firm's ESG pillar scores influence its value and financial performance in the air transport context. To do so, we employed the market-to-book ratio as a proxy of the company's value defined as price of equity divided by its book value. Over the course of time, firms are expected to grow and achieve higher profit records, therefore, the book value no longer defines the real value as there would be an important gap between book and market value of equity. The Fama-French three-factor model is one of the most well-known tools in asset pricing theory addressing the issue. They argue that the market-to-book effect is among the facts that cannot be explained in the capital asset pricing model (CAPM), but it can be captured by their proposed model [67]. Fama and French introduced the market-to-book effect as a behavioral anomaly. Based on this effect, they discovered that firms with low ratio (a low stock price relative to book value) tend to be persistently distressed. Conversely, high value (a high stock price relative to book value) is associated with sustained strong profitability [68]. In other words, a negative difference between market value and book value is an indicator of potential impairment, especially if the difference continues over time [69]. However, if the market value is higher than the book value, this shows the potential ability to generate good profits or value increase for the company and its shareholders. Adding sustainability issues to this debate, we expect that ESG disclosures have a positive relationship with the market-to-book ratio, since firms with better sustainability records tend to have higher market value above their book value. Rational investors usually tend to pay more for a company with high sustainability records, and do not hold a share of companies with a worse social reputation. On this basis, we propose the first study hypothesis as follows.

Hypothesis 1 (H1). Corporate environmental, social, and governance pillar scores are positively related to the market-to-book ratio.

We also employ Tobin's $Q$ as representative of a firm's financial performance to evaluate how this measure reacts with the firm's sustainability performance. In regards to the scientific literature background, the academic debate has been going on for more than 50 years to evaluate the implications of launching these standards on a firm's performance [12]. By reviewing the argument, research 
yield seems to be split into two main streams. First, the encouraging view says that environmental and social responsibility can be consistent with shareholder wealth maximization as well as reaching broader societal goals. Reference [33] pointed out that implementation of ESG disclosures, through their influence on corporate financial performance and imposed risks on broader economic growth and financial market stability, will influence investment return. On the opposite side, there is a view arguing that these practices are often a manifestation of managerial agency problems inside the firm and, hence, problematic [70-72]. From the empirical perspective, this has been proved in some studies with controversial results $[6,11]$. Some research suggests that ESG activities have a positive impact on a firm's performance $[13,14]$. However, other studies conclude that a firm's performance is negatively impacted by ESGs [15]. Taking the issue into consideration more precisely, according to a survey of 132 empirical papers in reference [73], more than $78 \%$ of these studies report a positive relationship between corporate sustainability and corporate financial performance. Based on this discussion and in accordance with related studies in the air transport industry, we also considered a positive relationship between these two categories. It is also worth noting that long-term sustainability can improve a firm's benefit through improved relations with stakeholders and reduced cost of conflicts with them, reputation creation, and employee productivity [60]. Therefore, we defined the second hypothesis as:

Hypothesis 2 (H2). Corporate environmental, social, and governance pillar scores are positively associated with a firm's financial performance.

\section{Methodology}

\subsection{Data and Sample Selection}

This study collected panel data in order to test the impact of sustainability activities on firm value and performance of airlines over the period from 2013 to 2019 using multiple regression analysis. This method has been widely used in prior studies (e.g., $[16,17,48]$ ). The data used in this research are drawn from the Thomson Reuters Eikon database. It is largely explored for academic research and covers the most comprehensive historical financial data since the 1950s. This database also provides economic, social, and governance (ESG) information on over 5000 globally listed companies, including airlines. The Thomson Reuters ESG pillar scores were designed to transparently and objectively measure a company's relative sustainability performance across ten themes (emissions, environmental product innovation, human rights, shareholders, etc.) based on reported company data. It should be noted that the ESG pillar scores provided by this database are an annual score for each airline ranging from 0 to 100 points. These scores are available in the database as the weighted average of the scores achieved in more than 70 key performance indicators calculated from 400 data points that make it up.

During the data exploration and preparation stage, we faced some challenges as follows. First, as in almost all time series analyses, we encountered missing data values for the variables in the observation of interest. Using the mean imputation technique, we replaced each of the missing values with the mean of the observed data for each airline. The advantage of using this method is that it is simple to implement, and no observations are excluded from the model [74]. Second, we also faced some data values which are significantly different from others. We identified those data points as outliers and removed them from the sample. The data are unbalanced panel data with 27 sampled worldwide airlines.

For the purpose of this research, we used a range of variables regarding firms' value, financial, and sustainability performance of airlines, as well as six control variables. The explanation of these variables is given in the following sections.

\subsection{Variables}

\subsubsection{Dependent Variables}

In this study, we employed a slightly different approach to study airlines' value as a sign of financial distress. The market-to-book ratio was used as a proxy of firm value defined as the market 
value of equity divided by its book value. The ratio is an important firm-level predictor for return in all countries and in almost all categories [75]. Additionally, consistent with $[16,17,76]$ we adopted Tobin's $\mathrm{Q}$ for the analysis of the relationship between sustainability measures and financial performance in the airline industry. Several definitions of Tobin's $Q$ have been proposed in the literature; however, these different methods tend to yield similar values for Tobin's Q [77]. In this study, in line with reference [11], we used Tobin's $Q$ as total market value divided by total assets and took the natural logarithm value to eliminate the effect of outliers.

\subsubsection{Main Variables}

We employed the pillar scores for environmental, social, and governance dimensions as measures of the sustainability performance of airlines. The measurement is based on the rated ESG factors for each firm-year in the Thomson Reuters Eikon database. The database rates three pillars based on publicly available reported information related to each dimension. The environmental pillar is concerned with a company's impact on living and non-living natural systems, including air, land, and water, as well as complete ecosystems. It reflects how well a company uses the best management practices to avoid environmental risks and capitalize on environmental opportunities in order to generate long-term shareholder value. The social pillar evaluates a company's capacity to generate trust and loyalty with its workforce, customers, and society, through its commitment to developing the best working conditions. It reflects the company's reputation and the safety of its license to operate, which are key factors for determining its ability to generate long-term shareholder value. Finally, the corporate governance criteria refer to a company's systems and processes, ensuring that its board members and executives act in the interests of its long-term shareholders. It reflects a company's capacity through its use of methods and innovative practices to direct and control its rights and responsibilities through the creation of incentives, as well as checks and balances in order to generate long-term shareholder value. These measures entail a careful process to standardize the information and guarantee that it is comparable across the entire range of companies [78].

\subsubsection{Control Variables}

Consistent with empirical research, the current study uses six control variables that can affect a firm's value and financial performance: profitability, leverage, dividend payout ratio, size, age, and the number of years an airline has been reporting an ESG score. These control variables are used in the literature examining the effect of sustainability measures on firm performance in different industries such as banking [79] and the restaurant context [80], as well as on studying companies contributing to the United Nations Global Impact [81]. Return on assets (ROA) is suggested as a proxy for a firm's operating profitability. It is defined as a firm's operating efficiency regardless of its financial structure. $\mathrm{ROA}$ is calculated by dividing a company's operating profit prior to financing costs by total assets. Firms with higher profitability are likely to achieve better market performance and consequently have more chances to make eco-friendly and sustainability investments $[80,82]$. Leverage ratio (Lev) is broadly suggested in different industries to control a firm's capital structure. According to reference [83], a firm's capital structure has implications for the firm's performance. The theoretical basis arising from trade-off theory implies that low-growth firms having stable cash flows and tangible assets should consider using more debt, because they can use tax shields and would incur lower costs if distress occurs. Airlines appeared to have high average indebtedness and low turnover, therefore, consistent with this characteristic, especially as some airlines have negative equity [84]. They introduce the tax advantage of debt where a firm with less cost disadvantage of financial distress can actually increase debt to a certain level.

Likewise, the dividend pay-out ratio (Div) has been proposed to have an implication on a firm's financial decisions. It is considered as an illustrative channel to convey the wealth to shareholders as well as signals to investors regarding a firm's financial status [85]. This is because shareholders and investors have inferior information to the firm's insiders. This asymmetry establishes a potential inaccuracy 
in pricing the firm's claims by market and, therefore, provides a positive contribution for corporate financing decisions [86]. This makes investors hesitate to invest in an unbalanced information situation due to the potential increase in financial doubt. Therefore, the payout system has been proposed in corporate finance as an alarm signal of a firm's performance and financial situation in order to control the investment risk [85]. Based on the study in reference [87], the higher the dividends, the higher the firm value. Given this, we expect a positive relationship between performance and dividends. From an empirical perspective, we use the debt ratio for a firm's leverage, which is defined as total liabilities over total assets. This is consistent with both reference [16] and reference [17] as they also proposed it as a control variable to consequently have an implication on an airline's value and performance.

Consistent with references $[16,17,88-90]$ for the purpose of this study we also included firm size in our control variables. In theory, based on economies of scale, large firms perform better than small firms because large firms tend to achieve better efficiencies in their operations, including greater purchasing power and reduced costs $[16,91]$. This control variable should be particularly relevant because of the possible appearance of scale economies related to environmentally and socially oriented investments and initiatives [81]. There are different proxies introduced for the size of the firm; in this study, following reference [16], we used the natural log of total assets. Furthermore, based on references [17,92] firm age has also been used to discover the effect of sustainability activities on airlines' financial performance. We considered the year in which the airline started doing business as the base to calculate the firm's age. This study also used two initiative variables to (1) control for the number of years for which the airlines have been contributing to sustainability practices (RepESGs) and (2) check for airline type (TpDummy). By RepESG, we mean the difference between airlines in terms of the number of years for which they have been disclosing sustainability measures which we consider as an influential factor for the purpose of the current research. Meanwhile, TpDummy is a dummy variable to check the effect of airline type. This is important as the airlines' performance is proved to be different depending on the type of service [93]. For this purpose, in accordance with reference [17], we referred to reference [42] to divide air carriers into full-service and low-cost carriers to value the dummy. In addition, we also referred to the international civil aviation organization [94] to confirm the type of some of the airlines within the sample. Table 2 summarizes the full list of variables used in this study.

Table 2. Description of variables.

\begin{tabular}{|c|c|c|}
\hline Variable & Definition & Description \\
\hline \multicolumn{3}{|c|}{ Dependent Variables } \\
\hline MB & Market-to-book ratio & $\begin{array}{l}\text { As defined by Thomson Reuters Eikon database, it is a } \\
\text { security's price divided by its book value per share actual. }\end{array}$ \\
\hline TQ & Tobin's Q & Tobin's $Q=$ market value/total assets \\
\hline \multicolumn{3}{|c|}{ Explanatory Variables } \\
\hline Env & Environmental pillar score & Thomson Reuters score for environmental disclosure. \\
\hline Soc & Social pillar score & Thomson Reuters score for social disclosure. \\
\hline Gov & Governance pillar score & Thomson Reuters score for governance disclosure. \\
\hline ROA & Return on assets & $\begin{array}{l}\text { As defined by Thomson Reuters Eikon database, ROA } \\
\text { measures a company's operating efficiency regardless of its } \\
\text { financial structure (in particular, without regard to the } \\
\text { degree of leverage a company uses) and is calculated by } \\
\text { dividing a company's operating profit to financing costs by } \\
\text { total assets. }\end{array}$ \\
\hline Div & Dividend pay-out ratio & $\begin{array}{c}\text { Defined as the average gross dividends-common stock over } \\
5 \text { fiscal years divided by average of income available to } \\
\text { common excluding extraordinary items for the sample } \\
\text { period and is expressed as percentage. }\end{array}$ \\
\hline
\end{tabular}


Table 2. Cont.

\begin{tabular}{|c|c|c|}
\hline Variable & Definition & Description \\
\hline \multicolumn{3}{|c|}{ Explanatory Variables } \\
\hline Lev & Leverage ratio & Defined as total liabilities over total assets. \\
\hline Size & Firm size & Natural logarithm of total assets. \\
\hline Age & Firm age & $\begin{array}{l}\text { The number of years since company's foundation (start } \\
\text { doing business). }\end{array}$ \\
\hline RepESG & ESGs reporting & Number of years the airline has been reporting ESG scores \\
\hline TpDummy & Type dummy & $\begin{array}{l}\text { The dummy for type of airline, i.e., whether it is full-service } \\
\text { or low-cost one. }\end{array}$ \\
\hline
\end{tabular}

\subsection{Model Specification}

To pursue the research hypothesis and accomplish this study's purpose, the analysis was conducted to test the effects of three environmental, social, and governance sustainability performance indicators on financial distress, measured by market-to-book ratio and firm financial performance, using Tobin's $Q$. Following references $[16,17,42]$, panel data analysis has been applied to detect the statistical relationship between them. Panel data is a dataset in which entities are observed over time. It allows us to control for variables which cannot be observed or measured and to account for individual heterogeneity [95]. According to the hypotheses mentioned above, we formulated two independent regression equations in the following empirical models, including dependent and explanatory variables as follows:

Model 1

$$
\begin{aligned}
& \mathrm{MB}_{\text {it }}=\alpha+\beta_{1} \mathrm{Env}_{\text {it }}+\beta_{2} \mathrm{Soc}_{i t}+\beta_{3} \mathrm{Gov}_{i t}+\beta_{4} \mathrm{ROA}_{i t}+\beta_{5} \mathrm{Div}_{\mathrm{it}}+ \\
& \beta_{6} \text { Lev }_{i t}+\beta_{7} \text { Size }_{i t}+\beta_{8} \text { Age }_{i t}+\beta_{9} \text { RepESG }_{i t}+\beta_{10} \text { TpDummy }_{i t}+\varepsilon_{i t}
\end{aligned}
$$

Model 2

$$
\begin{gathered}
\text { Tobin'sQ }_{\text {it }}=\alpha+\beta_{1} \text { Env }_{\text {it }}+\beta_{2} \text { Soc }_{i t}+\beta_{3} \text { Gov }_{i t}+\beta_{4} \text { ROA }_{i t}+\beta_{5} \text { Div }_{i t}+ \\
\beta_{6} \text { Lev }_{\text {it }}+\beta_{7} \text { Size }_{i t}+\beta_{8} \text { Age }_{i t}+\beta_{9} \operatorname{RepESG}_{\text {it }}+\beta_{10} \text {TpDummy }_{i t}+\varepsilon_{\text {it }}
\end{gathered}
$$

A clear strategy was followed to select the best fit predictor for each model based on reference [96]. Models were fitted in the environment of R [97] and RStudio [98] using utilities in the R-package 'plm' [99]. Our dataset was based on a panel consisting of 27 airlines from 2013 to 2019. However, missing data mean that the effective number of observations is lower; the panel would thus be unbalanced. While running the models as an unbalanced panel, we observed the loss of a significant volume of data by R-studio (the software reduced our 27 airlines to 23). Therefore, we decided to fill in the missing values by the mean of each airline in order to keep the data. We estimated both fixed and random effect models by running the Hausman test to compare two estimators. Both the fixed effect $[17,42,76]$ model and random effect model $[16,100]$ have been broadly used in the empirical literature. The results of the test for the two models used in this study denote $p$-values higher than 0.05. Thus, we cannot reject the null hypothesis, and the random individual model was found to be the preferred method to pursue the study aims.

\section{Empirical Results}

\subsection{Descriptive Statistics}

Summary statistics for the research variables are presented in Table 3. The market-to-book ratio shows a mean value of 1.57, ranging from 0.38 to 3.74 . This means that airlines' stock is expensive and the current market value of airline assets is different from records on balance sheets. Another reason for this high ratio is because of airlines' intangible assets, normally ignored in book value. Tobin's $Q$ is 
distributed between 0.06 and 1.78 , with a mean of 0.46 and a standard deviation of 0.73 . This means that the studied airlines' replacement costs are greater than the value of their assets. Return on assets (ROA) is low, as shown, with a mean value of 0.03 , indicating the sampled firms' inefficient performance in converting the invested capital into operating profit. We can also see that the sustainability-related ESG pillar scores of environmental, social, and governance indicators have an overall mean of 50.30 . The governance pillar has the highest average score of 53.41, followed by the social pillar. This denotes that acting in the best interests of long-term shareholders is more important for board members and executives of airlines. The mean score on the environmental pillar is 44.83 , showing a weakness of efforts to integrate policies and systems for environmental management in airlines. Take into account that, although the minimum score for each domain is 0 and the maximum is 100 , the sample airlines never reach 100 in the entire period, with a minimum (maximum) of 0.21, 1.04, and 7.37 (95.36, 93.09, and 96.07), respectively. This highlights the large variation in the sustainability performance of airlines. The dividend pay-out ratio (Div) has a mean of 0.19 and firm leverage ratio (Lev) shows a minimum (maximum) value of 0.00 (1.20), with a mean value of 0.70 . It is also worth noting that the RepESG shows a mean of 8.5 , indicating that the participation of airlines in reporting sustainability records is less than 50\% (since Thomson Reuters started to launch ESG disclosures in 2002, based on the time period of the study, the potential maximum number of years for each airline is 17).

Table 3. Summary of descriptive statistics.

\begin{tabular}{cccccccccccc}
\hline Var/Index & MB & TQ & Env & Soc & Gov & Lev & ROA & Div & Size & Age & RepESG \\
\hline Mean & 1.57 & 0.46 & 44.83 & 52.66 & 53.41 & 0.70 & 0.03 & 0.19 & 18,237 & 39 & 8.5 \\
\hline Median & 1.45 & 0.37 & 48.06 & 52.70 & 54.54 & 0.73 & 0.03 & 0.20 & 15,500 & 44 & 8 \\
\hline Max & 3.74 & 1.78 & 95.36 & 93.09 & 96.07 & 1.20 & 0.12 & 0.71 & 64,529 & 85 & 18 \\
\hline Min & 0.38 & 0.06 & 0.21 & 1.04 & 7.37 & 0.00 & -0.06 & 0.00 & 5092 & 3 & 1 \\
\hline Std. De & 0.73 & 0.33 & 22.99 & 20.34 & 25.06 & 0.23 & 0.03 & 0.18 & 14,115 & 23 & 4.03 \\
\hline Skewness & 0.87 & 1.55 & -0.39 & -0.34 & -0.13 & -0.71 & 0.12 & 0.83 & 0.91 & 0.07 & 0.39 \\
\hline Kurtosis & 0.15 & 2.69 & -0.70 & -0.09 & -0.15 & 1.37 & -0.03 & 0.09 & 0.29 & -1.4 & -0.72 \\
\hline
\end{tabular}

\subsection{Discussion of Results}

Prior to selecting which panel regression model to use, in order to identify potential endogenous variables, some robustness tests had to be carried out. First, we drew the correlation matrix for the study variables. In statistics, the correlation coefficient measures the strength and direction of a linear relationship between two variables. The value ranges between +1 and -1 . Tables 4 and 5 summarize the correlation matrix of variables for the market-to-book ratio (Table 4) and Tobin's Q panels (Table 5). Regarding the information provided, it is evident that there is a high correlation between the ESG dimensions. To clarify, the most relevant is that of the social pillar with the environmental score. Except for that, the absolute values for both model variables are under 0.5 , indicating an absence of a significant relationship between some variables. Second, as presented in Table 6, this study calculated the variance inflation factor (VIF) to identify the presence of multicollinearity. It aims to check whether two or more variables are highly correlated which might affect the estimation of the regression parameters [101]. It can be easily seen from the table that the test indicated no multicollinearity problems, since the variance inflation factor (VIF) results for all regression models was less than 5 [102]. 
Table 4. Correlation matrix for model with market-to-book ratio as dependent variable.

\begin{tabular}{|c|c|c|c|c|c|c|c|c|c|c|}
\hline & MB & Env & Soc & Gov & ROA & Div & Lev & Size & Age & RepESG \\
\hline $\mathrm{MB}$ & 1 & & & & & & & & & \\
\hline Env & $\begin{array}{l}-0.081 \\
(0.27)\end{array}$ & 1 & & & & & & & & \\
\hline Soc & $\begin{array}{l}-0.053 \\
(0.467) \\
\end{array}$ & $\begin{array}{c}0.81 \\
(7.67 \mathrm{E}-46)^{* * *} \\
\end{array}$ & 1 & & & & & & & \\
\hline Gov & $\begin{array}{c}0.21 \\
(0.00438) \\
\end{array}$ & $\begin{array}{c}0.35 \\
(0.00000)^{* * *} \\
\end{array}$ & $\begin{array}{c}0.31 \\
(0.00001)^{* * *} \\
\end{array}$ & 1 & & & & & & \\
\hline ROA & $\begin{array}{c}0.39 \\
(2.84 \mathrm{E}-08) \\
\end{array}$ & $\begin{array}{c}-0.34 \\
(0.00000)^{* * *} \\
\end{array}$ & $\begin{array}{c}-0.31 \\
(0.00001)^{* * *}\end{array}$ & $\begin{array}{c}-0.084 \\
(0.25) \\
\end{array}$ & 1 & & & & & \\
\hline Div & $\begin{array}{c}-0.11 \\
(0.138)\end{array}$ & $\begin{array}{l}-0.10 \\
(0.166)\end{array}$ & $\begin{array}{c}-0.14 \\
(0.0548)\end{array}$ & $\begin{array}{l}-0.052 \\
(0.474)\end{array}$ & $\begin{array}{c}0.06 \\
(0.409) \\
\end{array}$ & 1 & & & & \\
\hline Lev & $\begin{array}{c}0.08 \\
(0.275) \\
\end{array}$ & $\begin{array}{c}0.34 \\
(0.00000)^{* * *} \\
\end{array}$ & $\begin{array}{c}0.39 \\
(2.62 \mathrm{E}-08)^{* * *} \\
\end{array}$ & $\begin{array}{c}0.13 \\
(0.0674)\end{array}$ & $\begin{array}{c}-0.42 \\
(1.33 \mathrm{E}-09)^{* * *}\end{array}$ & $\begin{array}{c}-0.37 \\
(0.00000)^{* * *}\end{array}$ & 1 & & & \\
\hline Size & $\begin{array}{c}0.075 \\
(0.308) \\
\end{array}$ & $\begin{array}{c}0.45 \\
(6.27 \mathrm{E}-11)^{* * *}\end{array}$ & $\begin{array}{c}0.35 \\
(0.00000)^{* * *} \\
\end{array}$ & $\begin{array}{c}0.17 \\
(0.0219) *\end{array}$ & $\begin{array}{c}0.019 \\
(0.793) \\
\end{array}$ & $\begin{array}{l}-0.10 \\
(0.152)\end{array}$ & $\begin{array}{c}0.38 \\
(9.42 \mathrm{E}-08)^{* * *} \\
\end{array}$ & 1 & & \\
\hline Age & $\begin{array}{c}-0.30 \\
(0.0000361)\end{array}$ & $\begin{array}{c}0.46 \\
(3.72 \mathrm{E}-11)^{* * *}\end{array}$ & $\begin{array}{c}0.36 \\
(0.000000)^{* * *}\end{array}$ & $\begin{array}{l}-0.075 \\
(0.303)\end{array}$ & $\begin{array}{l}-0.069 \\
(0.344)\end{array}$ & $\begin{array}{l}-0.11 \\
(0.142)\end{array}$ & $\begin{array}{c}0.043 \\
(0.557)\end{array}$ & $\begin{array}{c}0.32 \\
(0.000000)^{* * *}\end{array}$ & 1 & \\
\hline RepESG & $\begin{array}{c}0.033 \\
(0.648)\end{array}$ & $\begin{array}{c}0.49 \\
(9.81 \mathrm{E}-13)^{* * *}\end{array}$ & $\begin{array}{c}0.43 \\
(9.18 \mathrm{E}-10)^{* * *}\end{array}$ & $\begin{array}{c}0.29 \\
(0.00006) * * *\end{array}$ & $\begin{array}{c}0.066 \\
(0.365)\end{array}$ & $\begin{array}{c}0.081 \\
(0.268)\end{array}$ & $\begin{array}{l}-0.000 \\
(0.998)\end{array}$ & $\begin{array}{c}0.22 \\
(0.00187)^{* * * *}\end{array}$ & $\begin{array}{c}0.45 \\
(7.55 \mathrm{E}-11)^{* * *}\end{array}$ & 1 \\
\hline
\end{tabular}

Signif. Codes: ${ }^{\prime * * * \prime \prime}$ if $p$-value $<0.001 ;^{\prime * * * \prime}$ if $p$-value $<0.01{ }^{\prime \prime * \prime}$ if $p$-value $<0.05 ;^{\prime} .^{\prime}$ if $p$-value $<0.1$. 
Table 5. Correlation matrix for model with Tobin's $Q$ as dependent variable.

\begin{tabular}{|c|c|c|c|c|c|c|c|c|c|c|}
\hline & TQ & Env & Soc & Gov & ROA & Div & Lev & Size & Age & RepESG \\
\hline TQ & 1 & & & & & & & & & \\
\hline Env & $\begin{array}{c}-0.47 \\
(9.88 \mathrm{E}-12)^{* * *}\end{array}$ & 1 & & & & & & & & \\
\hline Soc & $\begin{array}{c}-0.44 \\
(2.43 \mathrm{E}-10)^{* * *}\end{array}$ & $\begin{array}{c}0.81 \\
(7.67 \mathrm{E}-46)^{* * *}\end{array}$ & 1 & & & & & & & \\
\hline Gov & $\begin{array}{c}-0.02 \\
(0.782)\end{array}$ & $\begin{array}{c}0.35 \\
(0.00000)^{* * *}\end{array}$ & $\begin{array}{c}0.31 \\
(0.00001)^{* * *}\end{array}$ & 1 & & & & & & \\
\hline ROA & $\begin{array}{c}0.56 \\
(4.89 \mathrm{E}-17)\end{array}$ & $\begin{array}{c}-0.34 \\
(0.00000)^{* * *}\end{array}$ & $\begin{array}{c}-0.31 \\
(0.00001)^{* * *}\end{array}$ & $\begin{array}{l}-0.084 \\
(0.25)\end{array}$ & 1 & & & & & \\
\hline Div & $\begin{array}{c}0.20 \\
(0.00596) * *\end{array}$ & $\begin{array}{c}-0.10 \\
(0.166)\end{array}$ & $\begin{array}{c}-0.14 \\
(0.0548)\end{array}$ & $\begin{array}{l}-0.052 \\
(0.474)\end{array}$ & $\begin{array}{c}0.06 \\
(0.409)\end{array}$ & 1 & & & & \\
\hline Lev & $\begin{array}{c}-0.34 \\
(0.000000)^{* * *}\end{array}$ & $\begin{array}{c}0.34 \\
(0.00000)^{* * *}\end{array}$ & $\begin{array}{c}0.39 \\
(2.62 \mathrm{E}-08)^{* * *}\end{array}$ & $\begin{array}{c}0.13 \\
(0.0674)\end{array}$ & $\begin{array}{c}-0.42 \\
(1.33 \mathrm{E}-09) * * *\end{array}$ & $\begin{array}{c}-0.37 \\
(0.00000)^{* * *}\end{array}$ & 1 & & & \\
\hline Size & $\begin{array}{c}-0.19 \\
(0.00983)^{* *}\end{array}$ & $\begin{array}{c}0.45 \\
(6.27 \mathrm{E}-11)^{* * *} \\
\end{array}$ & $\begin{array}{c}0.35 \\
(0.00000)^{* * *} \\
\end{array}$ & $\begin{array}{c}0.17 \\
(0.0219) * \\
\end{array}$ & $\begin{array}{c}0.019 \\
(0.793) \\
\end{array}$ & $\begin{array}{l}-0.10 \\
(0.152)\end{array}$ & $\begin{array}{c}0.38 \\
(9.42 \mathrm{E}-08)^{* * *}\end{array}$ & 1 & & \\
\hline Age & $\begin{array}{c}-0.37 \\
(0.00000)^{* * *}\end{array}$ & $\begin{array}{c}0.46 \\
(3.72 \mathrm{E}-11) * * *\end{array}$ & $\begin{array}{c}0.36 \\
(0.000000)^{* * *}\end{array}$ & $\begin{array}{l}-0.075 \\
(0.303)\end{array}$ & $\begin{array}{l}-0.069 \\
(0.344)\end{array}$ & $\begin{array}{c}-0.11 \\
(0.142)\end{array}$ & $\begin{array}{c}0.043 \\
(0.557)\end{array}$ & $\begin{array}{c}0.32 \\
(0.000000) * * *\end{array}$ & 1 & \\
\hline RepESG & $\begin{array}{c}-0.0096 \\
(0.896)\end{array}$ & $\begin{array}{c}0.49 \\
(9.81 \mathrm{E}-13) * * *\end{array}$ & $\begin{array}{c}0.43 \\
(9.18 \mathrm{E}-10) * * *\end{array}$ & $\begin{array}{c}0.29 \\
(0.00006) * * *\end{array}$ & $\begin{array}{c}0.066 \\
(0.365)\end{array}$ & $\begin{array}{c}0.081 \\
(0.268)\end{array}$ & $\begin{array}{l}-0.000 \\
(0.998)\end{array}$ & $\begin{array}{c}0.22 \\
(0.00187)\end{array}$ & $\begin{array}{c}0.45 \\
(7.55 \mathrm{E}-11)^{* * *}\end{array}$ & 1 \\
\hline
\end{tabular}

Signif. Codes: ${ }^{\prime * * * \prime}$ if $p$-value $<0.001 ;^{{ }^{* * * \prime}}$ if $p$-value $<0.01 ;^{\prime * \prime \prime}$ if $p$-value $<0.05 ;^{\prime \prime}$ ' if $p$-value $<0.1$. 
Table 6. Variance inflation factor.

\begin{tabular}{ccccccccc}
\hline \multicolumn{8}{c}{ Panel with market-to-book ratio } \\
\hline Env & Soc & Gov & ROA & Div & Lev & Size & Age & RepESG \\
\hline 2.20 & 1.95 & 1.19 & 1.13 & 1.05 & 1.14 & 1.09 & 1.68 & 1.94 \\
\hline \multicolumn{10}{c}{ Pnvel with Tobin's Q } \\
\hline 2.00 & Soc & Gov & ROA & Div & Lev & Size & Age & RepESG \\
\hline
\end{tabular}

\subsubsection{Panel Data Analysis-Market-to-Book Ratio}

Table 7 presents the results of the main effects of the model with market-to-book ratio as dependent variable, which is panel I of the study. Panel I shows the results of testing the model, asserting that launching sustainable standards could impact the discrepancy between the book and market values. This model considers the environmental pillar score (Env), social pillar score (Soc), and governance pillar score (Gov) as the main explanatory variables.

Table 7. Empirical results for the market-to-book ratio panel I.

\begin{tabular}{cccc}
\hline Variables & Coefficients & z-Value & $p$-Value \\
\hline Env & 0.00050365 & 0.1639 & 0.86979 \\
\hline Soc & -0.00536202 & -1.7074 & 0.08775 \\
\hline Gov & 0.00380730 & 1.6070 & 0.10805 \\
\hline ROA & -0.08941674 & -0.0847 & 0.93248 \\
\hline Div & -0.11771785 & -0.4951 & 0.62050 \\
\hline Lev & 0.39616425 & 1.4709 & 0.14131 \\
\hline Size & 0.03715850 & 1.0048 & 0.31498 \\
\hline Age & 0.00149240 & 0.3195 & 0.74932 \\
\hline RepESG & 0.00437381 & 0.2872 & 0.77393 \\
\hline TpDummy & -0.01922893 & -0.0696 & 0.94451
\end{tabular}

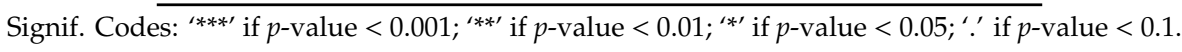

The results reveal that both Env and Gov are positive but insignificantly associated with a firm's market-to-book ratio, implying that an increase in both pillars leads to a higher ratio. On the basis of these findings, we find support for $\mathrm{H} 1$ regarding a positive relationship between each of the ESG factors with the market-to-book ratio. The higher ratio suggests that an airline's effort to improve their Envs and Govs could be seen as a potential profit-making opportunity by investors. This is because a high market-to-book ratio means that the firm has earning growth and a positive return on its assets, signifying a good enough reason to own its stock. Therefore, airlines' investment in environmental and governance practices, such as using re-usable resources, innovation, reducing emissions, management structure, shareholders maximizing benefits, and implementation of a sustainability reporting strategy, may also result in a higher market-to-book ratio. Consequently, the firm is also likely to have sustained profitability. Social disclosure is negative and significant, denoting that investing in social image leads to a drawback in ratio and, potentially, financial distress. In contrast to environmental and governance factors, the social pillar outcome does not support $\mathrm{H} 1$ of the study. This result seems to be surprising given the preponderance of capital market implication of social performance and social disclosure implying that investors in general place a relatively high value on firms who are seen to better address their social responsibilities. One possible reason for this finding could be the fact that investors do not 
give weight to social-based practices, such as human rights and product responsibility, and they prefer to value more tangible environmental and governance activities.

In terms of the control variables, we did not find any significant statistical effect on the market-to-book ratio. ROA and dividends negatively influence this variable. On the contrary, size, leverage, and age are found to have a positive relationship with the dependent variable. Finally, the TpDummy is not significant, showing that further dividing airlines into sub-categories of full-services and low-costs is not necessary. The result of two Env and Gov and size is consistent with a paper recently conducted [103], in which the author also finds that companies with a higher ESG (the ESG combined score) score resulted in a higher market-to-book ratio along with a broad range of financial ratios, such as return on investment and firm size.

\subsubsection{Panel Data Analysis-Tobin's Q}

Likewise, the results of the effects from the panel with Tobin's $Q$ as the dependent variable (panel II) are provided in Table 8. Panel II tests how corporate efficiency is related to sustainability activities. Like the model with the market-to-book ratio, here also the models considered the environmental, social, and governance categories as the main explanatory variables.

Table 8. Results for the full panel Tobin's Q panel II.

\begin{tabular}{|c|c|c|c|}
\hline Variables & Coefficients & z-Value & $p$-Value \\
\hline Env & 0.0087968 & 2.6325 & $0.008477^{* *}$ \\
\hline Soc & -0.0102770 & -3.0021 & $0.002681^{* *}$ \\
\hline Gov & 0.0035723 & 1.3020 & 0.192908 \\
\hline ROA & -1.6335460 & -1.4272 & 0.153514 \\
\hline Div & -0.1635009 & -0.6208 & 0.534699 \\
\hline Lev & -0.0680228 & -0.2127 & 0.831583 \\
\hline Size & 0.0499891 & 1.1749 & 0.240036 \\
\hline Age & -0.0037735 & -0.5409 & 0.588605 \\
\hline RepESG & 0.0153358 & 0.8783 & 0.379808 \\
\hline TpDummy & 0.1208856 & 0.2908 & 0.771181 \\
\hline
\end{tabular}

In line with the results of Panel I, a positive relationship is evident between the environmental and governance pillars and an airline's financial performance, implying that the firm's growth in these sustainability directions improves the airline's financial performance. This is especially true for the environmental dimension, as it is doubly significant. Therefore, $\mathrm{H} 2$ of the study appears to gain support from environmental and governance dimensions, stating that both directly affect airlines' financial efficiency. Consistent with reference [11], this result implies that airlines with environmental activities tend to be more efficient. This is especially important as, in today's highly competitive situation, employing more prudent environmental policies may provide an advantage for the airline. Put in perspective, the environmental pillar involves using renewable resources, innovation, and reducing emissions, where making progress in each will lead to more efficient operations for the airline. Regarding renewable resources, for example, some opportunities to reduce energy consumption are suggested by reference [104]. These suggestions include the establishment of more fuel-efficient aircraft technology, more direct flight patterns, and aircraft movements throughout the flight cycle. In addition, for innovation and reducing emissions, reference [105] defined technology-based (i.e., adopting novel or advanced technologies) and process-based (enhancing process efficiency in order to obtain higher utilization of capacity and simple procedures and omit resource-wasting processes) innovations for airlines, where they also prove that both innovation categories positively affect the 
firm's revenue. Overall, improving these three environmental initiatives leads to less fuel consumption for the airline which accounts for $25 \%-35 \%$ of total operating costs, and brings higher financial performance consequently $[106,107]$.

The same is true for the governance dimension of airlines. This perspective considers both stakeholder and shareholder-oriented pillar strategy since it covers the management, shareholders, and CSR policies of the firm. Our results show that a company's overall development in these three dimensions will also have a positive implication for its financial efficiency. This makes sense especially for the management structure of a company, which corresponds to the shareholder theory standpoint. The finding is consistent with reference [108], where these researchers also find that a firm's investment in stakeholder management could complement shareholder value creation and consequently provide a basis for competitive advantage.

In contrast, the social pillar is negative and doubly significant, which is against the above-stated $\mathrm{H} 2$. The reason behind this outcome could be because of the costs involved in launching social policies, especially if costs failed to be covered by the benefits gained from the airline's efficiency. In other words, the airline's investment in the workforce, human rights, the community, and product responsibility seem to be an extra financial burden and not returned, at least in the short term. Therefore, it negatively influences the financial performance of the firm. In this view, we find the result weakens the argument that social disclosure reflects the firm's strong commitment to employees and other stakeholders building competitive advantage in the market. Based on this view, investors expect that participating in societal initiatives has a positive impact on the growth rate of a firm's future advances in bringing more cash flow. This finding is inconsistent with references $[8,11,17]$. For example, reference [8] found that social disclosure is associated with higher efficiency and values (growth rate of future cash flow) for the firms which is contradicted with the general perception of investors globally who now care about a firm's social performance and mirroring the value attached to social screens.

Similar to Panel I, control variables appear to have no statistical significance in this panel. Leverage shows the negative impact on the dependent variable where, in comparison with panel I, the sign is different. This seems to suggest that every increase in airlines' leverage will cause a decrease in their financial performance. On the contrary, like panel I, size is found to have a positive relationship with Tobin's Q. Adding this result to sustainability performance, there is support from a theoretical background arguing that larger firms have a higher operational effect and are more visible in society. Therefore, the larger the size, the more capability (and eagerness) to invest in ESG issues [88], and a potential higher financial efficiency for the firm. Our finding is inconsistent with the outcomes of previous studies that also consider the size variable in examining the influence of sustainability initiatives on financial performance in the airline industry $[15,48]$. The possible justification for this inconsistency is dissimilarity in the employed data set and model specifications. This finding, however, is in line with reference [17], who also found the positive effect of size on financial performance. Finally, the TpDummy in this panel is not significant, showing that further dividing airlines into sub-categories of full-services and low-costs is not necessary.

\section{Discussion}

Sustainability issues have recently risen in importance in the firm's value and financial performance perspective and among investors, academicians, and even government regulators. However, to date, research on the relationship between ESG factors' performance and a firm's value and financial performance has achieved limited advances in the air transport industry. More precisely, (1) from a sustainability perspective, no attention has been paid to separately analyzing the impact of ESG factors. Furthermore, (2) the association between sustainability performance and financial distress has not previously been studied. In order to fill these gaps, this study contributes to the tourism and sustainability literature, empirically testing the firm value, financial performance, and sustainability performance in each ESG dimension of airlines. There are some principal differences between this article and the related research in this area. Specifically, we studied the impact of sustainability 
performance on some new aspects: we considered the ESG components to study how airlines' voluntary implementation of these standards influences their valuation by employing market-to-book ratio as a proxy of firm value as well as a sign of potential financial distress. Additionally, we added the dummy variable to account for the type of airline. This was to check whether there is any significant difference in research outcome among full-service and low-cost carriers.

The empirical results show that for the exemplary companies considered in this study, on the one hand, environmental and governance pillars are positively associated with a firm's market-to-book ratio and Tobin's $Q$ in both models. We find that an increase in both pillar disclosures leads to a higher market-to-book ratio and financial performance of airlines. Based on this result, an airline's investment in environmental and governance practices, such as using re-usable resources, innovation, reducing emissions, having a better management structure, and implementation of a sustainability policy, makes it more attractive for the investors. The outcome particularly is of interest due to the fact that in today's highly competitive situation, employing more prudent environmental and governance policies may provide a considerable advantage for the airline.

On the other hand, paradoxically with the public perception that social activities reflect the business's strong commitment to employee and other stakeholders' benefits and consequently somehow provide competitive advantage at the market, social pillar as measured in this study was found to be negatively associated with both a firm's value and its financial performance. This shows that an airline's social activities result in lower market value and level of financial performance. Regarding the control variables, ROA and dividends are negative and insignificant across the panels. Conversely, size positively charges the dependent variable in both models. Leverage and age are found to be positive in panel I of market-to-book ratio, but both are negative in Tobin's $Q$ panel. The dummy for type of airlines is insignificant in both panels, showing that dividing airlines into full-service and low-cost carrier categories is not necessary. Overall, constructed based on the sampled airlines and applied methodology, our findings offer insight into the sustainability and financial performance linkage of air transport. The outcome of this study highlights the importance of considering sustainability practices in the industry. We find direct relationships between the environmental and governance sides of ESG, but indirect for the social disclosure part.

\section{Conclusions}

\subsection{Study Implications}

Study findings have implications for researchers from a theoretical perspective, and airline practitioners together with policy-makers from a managerial perspective. From an academic point of view, despite the recent developments in the tourism literature, the consequences of implementing sustainability standards on firm efficiency and performance remain controversial and scant. An issue invariably recurs in the discussion about financial performance: does implementing environmental, social, and governance disclosures improve a firm's financial performance? Notwithstanding, our sample and the period of time analyzed may help answer this question and enrich the body of literature. We opened up a new research line by separately relating three sustainability performance dimensions of airlines (ESGs) to their value and efficiency. The results can be considered in the development of the resource-base theory [11,59,60], legitimacy theory [64] and the stakeholder theory [65] in the evolving field of sustainability. We investigate the possible relationships linking sustainability initiatives to the value and financial performance outcomes of airlines. However, the underlying mechanism of the relationship is still poorly understood. Therefore, academics can take consideration of our findings and study different samples of airlines in different time periods to (1) check whether the results are consistent and (2) discover the answer to why social pillars have a negative relationship with ESGs.

Second, airline industry practitioners, i.e., executives and managers, may also find these results interesting and informative in regard to their sustainability issues. Specifically, managers may consider the results of such studies in order to make the most sustainable investment and target the priorities of 
the firm. This makes more sense on recalling the fact that firms' resources are scarce, and they need to operate efficiently. Based on the current study's results, holding other things constant, we suggest that an airline's investment in environmental and governance practices will be rewarded with value and efficiency opportunities in the market space. In this way, an airline's investment to provide better environmental (consistent with reference [11]) and governance status could result in a higher market-to-book ratio and revenue from invested funds. The environmental pillar involves using renewable resources, innovation, and reducing emissions. With renewable resources, for example, as suggested by reference [104], there are some opportunities to reduce energy consumption, such as more fuel-efficient aircraft technology, more direct flight patterns, and aircraft movements throughout the flight cycle. In addition, for innovation and reducing emissions, reference [105] defined technology-based and process-based innovations for airlines, where they also prove that improvement in both innovation categories positively affect the firm's revenue. Overall, based on our results, improving these three environmental factors leads to less fuel consumption, which accounts for $25 \%-35 \%$ of total operating costs of airlines and achieves higher financial performance for the firm [106,107]. In the governance perspective, initiatives in the management structure of firms could be considered. Such activities may include launching an independent board of directors to reduce agency costs, providing more accurate reporting system for financial and operating sections, and encouraging shareholders to participate in firm's decision-making process. This may lead to enhancement of market competitiveness by bringing advanced climate change policies and guarantee the promotion of transparency toward shareholders so as to gain their trust. Finding of social disclosure also could be informative for the practitioners. Interestingly, the results indicate that investigated airlines will not have higher value and financial performance enhancement from social sustainability practices. This outcome denotes that investing in social image leads to a drawback in ratios and could be a potential sign of financial distress. Possible justification may argue that investors do not weight social-based practices as highly as more tangible environmental and governance activities.

In summary, a lack of sustainability initiatives on a firm's financial records implies the need for more communication and understanding of the topic. Results of this study may encourage airline practitioners to include environmental and governance performance metrics, since it may also improve the financial efficiency of the firm. Another insight is that policy-makers need to see the value in improving sustainability disclosure for the airline industry. By understanding these practices, they will have a more comprehensive view of factors influencing shareholders' wealth maximization principles in the air transport industry.

\subsection{Limitations and Future Research}

This study encountered some limitations. First, the finding is applicable to just a small proportion of airlines, depending on the best ESG data available in the Eikon database. This relatively small sample size could be extended with a larger set of airlines in future research. We also recommend an in-depth analysis of both full-service and low-cost airlines. In this view, qualitative comparative analysis (QCA) could be considered. The method has been suggested by a recent review study [109] to examine these sub-fields in the corporate governance domain. Finally, in the future, it would be interesting to expand the firm's value analysis to a larger sample, in order to investigate the reflection of an airline's value as a result of the promotion of sustainability records. Therefore, it could be interesting to make the financial distress factor available in this context, especially with regard to the recent unexpected COVID-19 pandemic.

Author Contributions: Conceptualization, Y.A., X.L. and X.C.-T.; methodology, Y.A., X.L. and X.C.-T.; software, Y.A., X.L. and X.C.-T.; validation, Y.A., X.L. and X.C.-T.; formal analysis, Y.A., X.L. and X.C.-T.; resources, Y.A., X.L. and X.C.-T.; data curation, Y.A., X.L. and X.C.-T.; writing-original draft preparation, Y.A., X.L. and X.C.-T.; writing-review and editing, Y.A., X.L. and X.C.-T.; visualization, Y.A., X.L. and X.C.-T.; supervision, X.L. and X.C.-T. All authors listed have significantly contributed to the development of the writing of this article. All authors have read and agreed to the published version of the manuscript. 
Funding: This project has received funding from European Union's Horizon 2020 research and innovation program under the Marie Skłodowska-Curie grant agreement NO. 713679 and from the Universitat Rovira i Virgili (URV).

Conflicts of Interest: The authors declare that there is no conflict of interest.

\section{References}

1. Belobaba, P.; Odoni, A.; Barnhart, C. (Eds.) The Global Airline Industry; John Wiley \& Sons: Hoboken, NJ, USA, 2009; ISBN 9780470740774.

2. ATAG Facts and Figures. Available online: https://www.atag.org/facts-figures.html (accessed on 1 June 2020).

3. IATA. Cargo Sustainability: Finding a Future for Air Freight. Available online: https://www.iata.org/en/ programs/cargo/sustainability (accessed on 1 June 2020).

4. Campbell, J.L. Why would corporations behave in socially responsible ways? An institutional theory of corporate social responsibility. Acad. Manag. Rev. 2007, 32, 946-967. [CrossRef]

5. Eccles, R.G.; Serafeim, G. The performance frontier: Innovating for a sustainable strategy. Harv. Bus. Rev. 2013, 91, 17-18.

6. Duque-Grisales, E.; Aguilera-Caracuel, J. Environmental, Social and Governance (ESG) Scores and Financial Performance of Multilatinas: Moderating Effects of Geographic International Diversification and Financial Slack. J. Bus. Ethics 2019, 1-20. [CrossRef]

7. Escrig-Olmedo, E.; Fernández-Izquierdo, M.Á.; Ferrero-Ferrero, I.; Rivera-Lirio, J.M.; Muñoz-Torres, M.J. Rating the raters: Evaluating how ESG rating agencies integrate sustainability principles. Sustainability 2019, 11, 915. [CrossRef]

8. Qiu, Y.; Shaukat, A.; Tharyan, R. Environmental and social disclosures: Link with corporate financial performance. Br. Account. Rev. 2016, 48, 102-116. [CrossRef]

9. Su, C.H.; Chen, C.D. Does sustainability index matter to the hospitality industry? Tour. Manag. 2020, 81, 104158. [CrossRef]

10. Liew, V.K. The effect of novel coronavirus pandemic on tourism share prices. J. Tour. Futures 2020. [CrossRef]

11. Xie, J.; Nozawa, W.; Yagi, M.; Fujii, H.; Managi, S. Do environmental, social, and governance activities improve corporate financial performance? Bus. Strateg. Environ. 2019, 28, 286-300. [CrossRef]

12. Eliwa, Y.; Aboud, A.; Saleh, A. ESG practices and the cost of debt: Evidence from EU countries. Crit. Perspect. Account. 2019, 102097. [CrossRef]

13. Fatemi, A.; Glaum, M.; Kaiser, S. ESG performance and firm value: The moderating role of disclosure. Glob. Financ. J. 2018, 38, 45-64. [CrossRef]

14. Yoon, B.; Lee, J.H.; Byun, R. Does ESG performance enhance firm value? Evidence from Korea. Sustainability 2018, 10, 3635. [CrossRef]

15. Lee, D.D.; Faff, R.W.; Langfield-Smith, K. Revisiting the Vexing Question: Does Superior Corporate Social Performance Lead to Improved Financial Performance? Aust. J. Manag. 2009, 34, 21-49. [CrossRef]

16. Lee, S.; Seo, K.; Sharma, A. Corporate social responsibility and firm performance in the airline industry: The moderating role of oil prices. Tour. Manag. 2013, 38, 20-30. [CrossRef]

17. Yang, A.S.; Baasandorj, S. Exploring CSR and financial performance of full-service and low-cost air carriers. Financ. Res. Lett. 2017, 23, 291-299. [CrossRef]

18. Goodman, K. CEO Duality and Its Impact on Large Publicly Traded Bank Holding Companies; Department of Finance, The University of Iowa: Iwoa city, IA, USA, 1995.

19. Eden, S. Environmental issues: Sustainable progress? Prog. Hum. Geogr. 2000, 24, 111-118. [CrossRef]

20. Moneva, J.M.; Archel, P.; Correa, C. GRI and the camouflaging of corporate unsustainability. Account. Forum 2006, 30, 121-137. [CrossRef]

21. Korhonen, J. Should we measure corporate social responsibility? Corp. Soc. Responsib. Environ. Manag. 2003, 10, 25-39. [CrossRef]

22. Hák, T.; Janoušková, S.; Moldan, B.; Dahl, A.L. Closing the sustainability gap: 30 years after “Our Common Future" society lacks meaningful stories and relevant indicators to make the right decisions and build public support. Ecol. Indic. 2018, 87, 193-195. [CrossRef]

23. Wiersum, K.F. 200 years of sustainability in forestry: Lessons from history. Environ. Manag. 1995, 19, 321-329. [CrossRef] 
24. Kuhlman, T.; Farrington, J. What is sustainability? Sustainability 2010, 21, 3436. [CrossRef]

25. Keeble, B.R. The Brundtland Report: “Our Common Future”. Med. War 1988, 4, 17-25. [CrossRef]

26. Starbuck, S.; LeBlanc, B.; Bramhall, J. Value of Sustainability Reporting-A Study; Ernst \& Young LLP. and Boston College: Newton, MA, USA, 2014; pp. 1-32.

27. GSSB Global Sustainability Standards Board. Available online: https://www.globalreporting.org/information/ about-gri/governance-bodies/Global-Sustainability-Standard-Board (accessed on 1 June 2020).

28. Global Reporting Initiatives. Sustainability Reporting Guidelines. 2002. Available online: https://www.r3-0. org/wp-content/uploads/2020/03/GRIguidelines.pdf (accessed on 1 June 2020).

29. Wilburn, K.; Wilburn, R. Using Global Reporting Initiative indicators for CSR programs. J. Glob. Responsib. 2013, 4, 62-75. [CrossRef]

30. Bowen, H.R. Social Responsibilities of the Businessman; University of Iowa Press: Iowa city, IA, USA, 1953.

31. Falck, O.; Heblich, S. Corporate social responsibility: Doing well by doing good. Bus. Horiz. 2007, 50, 247-254. [CrossRef]

32. Lozano, R. A holistic perspective on corporate sustainability drivers. Corp. Soc. Responsib. Environ. Manag. 2015, 22, 32-44. [CrossRef]

33. Hill, J. Environmental, Social, and Governance (ESG) Investing: A Balanced Analysis of the Theory and Practice of a Sustainable Portfolio; Elsevier BV: Amsterdam, The Netherlands, 2020.

34. Gillan, S.L.; Hartzell, J.C.; Koch, A.; Starks, L.T. Firms' Environmental, Social and Governance (ESG) Choices, Performance and Managerial Motivation. 2010; Unpublished Working Paper.

35. Lagasio, V.; Cucari, N. Corporate governance and environmental social governance disclosure: A metaanalytical review. Corp. Soc. Responsib. Environ. Manag. 2019, 26, 701-711. [CrossRef]

36. Humphrey, J.E.; Lee, D.D.; Shen, Y. The independent effects of environmental, social and governance initiatives on the performance of UK firms. Aust. J. Manag. 2012, 37, 135-151. [CrossRef]

37. Benlemlih, M. Corporate social responsibility and firm financing decisions: A literature review. J. Multinatl. Financ. Manag. 2017, 42-43, 1-10. [CrossRef]

38. Mak, B.L.; Chan, W.W. Environmental reporting of airlines in the Asia Pacific Region. J. Sustain. Tour. 2006, 14, 618-628. [CrossRef]

39. Forsyth, P. Environmental and financial sustainability of air transport: Are they incompatible? J. Air Transp. Manag. 2011, 17, 27-32. [CrossRef]

40. Cowper-Smith, A.; de Grosbois, D. The adoption of corporate social responsibility practices in the airline industry. J. Sustain. Tour. 2011, 19, 59-77. [CrossRef]

41. Arayssi, M.; Jizi, M.I. Does corporate governance spillover firm performance? A study of valuation of MENA companies. Soc. Responsib. J. 2019, 15, 597-620. [CrossRef]

42. Seo, K.; Moon, J.; Lee, S. Synergy of corporate social responsibility and service quality for airlines: The moderating role of carrier type. J. Air Transp. Manag. 2015, 47, 126-134. [CrossRef]

43. Tsai, W.H.; Hsu, J.L. Corporate social responsibility programs choice and costs assessment in the airline industry-A hybrid model. J. Air Transp. Manag. 2008, 14, 188-196. [CrossRef]

44. Heeres, J.L.; Kruijd, J.; Montgomery, E.; Simmons, J.J. Building Trust in the Air: Is Airline Corporate Sustainability Reporting Taking off? 2018, pp. 1-28. Available online: https://pwc.blogs.com/files/pwc_ airlinescr_web.pdf (accessed on 1 June 2020).

45. Inoue, Y.; Lee, S. Effects of different dimensions of corporate social responsibility on corporate financial performance in tourism-related industries. Tour. Manag. 2011, 32, 790-804. [CrossRef]

46. Nicolau, J.L. Corporate Social Responsibility. Worth-Creating ctivities. Ann. Tour. Res. 2008, 35, 990-1006. [CrossRef]

47. Park, S.Y.; Lee, S. Financial rewards for social responsibility: A mixed picture for restaurant companies. Cornell Hosp. Q. 2009, 50, 168-179. [CrossRef]

48. Lee, S.; Park, S.Y. Financial impacts of socially responsible activities on airline companies. J. Hosp. Tour. Res. 2010, 34, 185-203. [CrossRef]

49. Knutson, B.J. Editorial. J. Hosp. Leis. Mark. 2006, 14, 1-3.

50. Amankwah-amoah, J. Stepping Up and Stepping Out of COVID-19: New Challenges for Environmental Sustainability Policies in the Global Airline Industry. J. Clean. Prod. 2020, 271, 123000. [CrossRef] 
51. Coles, T.; Fenclova, E.; Dinan, C. Corporate social responsibility reporting among European low-fares airlines: Challenges for the examination and development of sustainable mobilities. J. Sustain. Tour. 2014, 22, 69-88. [CrossRef]

52. Wang, Q.; Wu, C.; Sun, Y. Evaluating corporate social responsibility of airlines using entropy weight and grey relation analysis. J. Air Transp. Manag. 2015, 42, 55-62. [CrossRef]

53. Arjomandi, A.; Seufert, J.H. An evaluation of the world's major airlines' technical and environmental performance. Econ. Model. 2014, 41, 133-144. [CrossRef]

54. Amaeshi, K.M.; Crane, A. Stakeholder Engagement: A Mechanism for Sustainable Aviation. SSRN Electron. J. 2011, 1-21. [CrossRef]

55. Hagmann, C.; Semeijn, J.; Vellenga, D.B. Exploring the green image of airlines: Passenger perceptions and airline choice. J. Air Transp. Manag. 2015, 43, 37-45. [CrossRef]

56. Lopatta, K.; Kaspereit, T. The World Capital Markets' Perception of Sustainability and the Impact of the Financial Crisis. J. Bus. Ethics 2014, 122, 475-500. [CrossRef]

57. Bryson, J.M.; Ackermann, F.; Eden, C. Putting the resource-based view of strategy and distinctive competencies to work in public organizations. Public Adm. Rev. 2007, 67, 702-717. [CrossRef]

58. Barrutia, J.M.; Echebarria, C. Resource-based view of sustainability engagement. Glob. Environ. Chang. 2015, 34, 70-82. [CrossRef]

59. Porter, M.E.; Kramer, M.R. Strategy and Society:The Link between Competitive Advantage and Corporate Social Responsibility. Harvard Bus. Harv. Bus. Rev. 2006, 84, 136-137.

60. Lourenço, I.C.; Branco, M.C.; Curto, J.D.; Eugénio, T. How Does the Market Value Corporate Sustainability Performance? J. Bus. Ethics 2012, 108, 417-428. [CrossRef]

61. Deegan, C. Introduction: The legitimising effect of social and environmental disclosures-A theoretical foundation. Account. Audit. Account. J. 2002, 15, 282-311. [CrossRef]

62. Suchman, M.C. Managing legitimacy: Strategic and institutional approaches. Acad. Manag. Rev. 1995, 20, 571-610. [CrossRef]

63. Davis, K. Assumption Responsibilities. Acad. Manag. J. 1973, 16, 312-322. [CrossRef]

64. Drempetic, S.; Klein, C.; Zwergel, B. The Influence of Firm Size on the ESG Score: Corporate Sustainability Ratings Under Review. J. Bus. Ethics 2019, 1-28. [CrossRef]

65. Freeman, R.E.; David, L.R. Stockholders and Stakeholders: A New Perspective on Corporate Governance. Calif. Manag. Rev. 1983, 25, 88-106. [CrossRef]

66. Garvare, R.; Johansson, P. Management for sustainability-A stakeholder theory. Total Qual. Manag. Bus. Excell. 2010, 21, 737-744. [CrossRef]

67. Fama, E.F.; French, K.R. Multifactor explanations of asset pricing anomalies. J. Financ. 1996, 51, 55-84. [CrossRef]

68. Fama, E.F.; French, K.R. Size and Book-to-Market Factors in Earnings and Returns. J. Financ. 1995, 50, 131-155. [CrossRef]

69. Bini, M.; Penman, S. Companies with Market Value Below Book Value are More Common in Europe than in the US: Evidence, Explanations and Implications. Report. KPMG. 24 April 2013. Available online: https:/assets. kpmg/content/dam/kpmg/pdf/2015/09/gvi-companies-with-market-vaule-below-book-value.pdf (accessed on 1 June 2020).

70. Benabou, R.; Tirole, J. Individual and corporate social responsibility. Economica 2010, 77, 1-19. [CrossRef]

71. Masulis, R.W.; Reza, S.W. Agency problems of corporate philanthropy. Rev. Financ. Stud. 2015, $28,592-636$. [CrossRef]

72. Ferrell, A.; Liang, H.; Renneboog, L. Socially responsible firms. J. Financ. Econ. 2016, 122, 585-606. [CrossRef]

73. Alshehhi, A.; Nobanee, H.; Khare, N. The impact of sustainability practices on corporate financial performance: Literature trends and future research potential. Sustainability 2018, 10, 494. [CrossRef]

74. Strike, K.; Emam, K.E.; Madhavji, N. Software cost estimation with incomplete data. IEEE Trans. Softw. Eng. 2001, 27, 890-908. [CrossRef]

75. Cakici, N.; Topyan, K. Book-to-Market Ratio. In Risk and Return in Asian Emerging Markets; Palgrave Macmillan: New York, NY, USA, 2014.

76. Theodoulidis, B.; Diaz, D.; Crotto, F.; Rancati, E. Exploring corporate social responsibility and financial performance through stakeholder theory in the tourism industries. Tour. Manag. 2017, 62, 173-188. [CrossRef]

77. Chung, K.H.; Pruitt, S.W. A Simple Approximation of Tobin's q. Financ. Manag. 1994, 70-74. [CrossRef] 
78. Reuters, T. Thomson Reuters ESG Scores. 2020. Available online: https://www.refinitiv.com/content/dam/ marketing/en_us/documents/methodology/esg-scores-methodology.pdf (accessed on 1 June 2020).

79. Miralles-Quirós, M.M.; Miralles-Quirós, J.L.; Hernández, J.R. ESG performance and shareholder value creation in the banking industry: International differences. Sustainability 2019, 11, 1404. [CrossRef]

80. Kim, B.; Lee, S. The impact of material and immaterial sustainability on firm performance: The moderating role of franchising strategy. Tour. Manag. 2020, 77, 103999. [CrossRef]

81. Ortas, E.; Álvarez, I.; Garayar, A. The environmental, social, governance, and financial performance effects on companies that adopt the United Nations Global Compact. Sustainability 2015, 7, 1932-1956. [CrossRef]

82. Waddock, S.A.; Graves, S.B. The Corporate Social Performance-Financial Performance Link. Stateg. Manaj. J. 1997, 18, 303-319. [CrossRef]

83. Kraus, A.; Litzenberger, R.H. A state-preference model of optimal capital structure. J. Financ. 1973, 28, 911-922. [CrossRef]

84. Pires, H.M.; Fernandes, E. Malmquist financial efficiency analysis for airlines. Transp. Res. Part E Logist. Transp. Rev. 2012, 48, 1049-1055. [CrossRef]

85. Moon, J.; Lee, W.S.; Dattilo, J. Determinants of the payout decision in the airline industry. J. Air Transp. Manag. 2015, 42, 282-288. [CrossRef]

86. Klein, L.S.; O’Brien, T.J.; Peters, S.R. Debt vs. equity and asymmetric information: A review. Financ. Rev. 2002, 37, 317-349. [CrossRef]

87. Gordon, M.J. Dividends, earnings, and stock prices. Rev. Econ. Stat. 1959, 41, 99-105. [CrossRef]

88. Qureshi, M.A.; Kirkerud, S.; Theresa, K.; Ahsan, T. The impact of sustainability (environmental, social, and governance) disclosure and board diversity on firm value: The moderating role of industry sensitivity. Bus. Strateg. Environ. 2020, 29, 1199-1214. [CrossRef]

89. Chen, E.; Gavious, I. Does CSR have different value implications for different shareholders? Financ. Res. Lett. 2015, 14, 29-35. [CrossRef]

90. Ding, D.K.; Ferreira, C.; Wongchoti, U. Does it pay to be different? Relative CSR and its impact on firm value. Int. Rev. Financ. Anal. 2016, 47, 86-98. [CrossRef]

91. Gelles, G.M.; Mitchell, D.W. Returns to Scale and Economies of Scale: Further Observations. J. Econ. Educ. 1996, 27, 259-261. [CrossRef]

92. Saeidi, S.P.; Sofian, S.; Saeidi, P.; Saeidi, S.P.; Saaeidi, S.A. How does corporate social responsibility contribute to firm financial performance? The mediating role of competitive advantage, reputation, and customer satisfaction. J. Bus. Res. 2015, 68, 341-350. [CrossRef]

93. Heshmati, A.; Kumbhakar, S.C.; Kim, J. Persistent and Transient Efficiency of International Airlines. Eur. J. Transp. Infrastruct. Res. 2018, 18, 213-238.

94. ICAO List of Low-Cost-Carriers (LCCs). Available online: https://www.icao.int/sustainability\%0D\%0A/ Documents/LCC-List.pdf\%0D\%0A (accessed on 1 February 2020).

95. Baltagi, B.H. Forecasting with panel data. J. Forecast. 2008, 27, 153-173. [CrossRef]

96. Torres-reyna, O. Panel Data using R-slides princeton university. Princet. Univ. 2010, 1-28. Available online: https://www.princeton.edu/ \{\}otorres/Panel101R.pdf (accessed on 1 July 2020).

97. R Development Core Team. Available online: https://cran.r-project.org/mirrors.html (accessed on 1 July 2020).

98. RStudio Team. Integrated Development for R; Version 1.2.1335; RStudio, Inc.: Boston, MA, USA, 2018.

99. Croissant, Y.; Millo, G. Panel data econometrics in R: The plm package. J. Stat. Softw. 2008, 27, 1-43. [CrossRef]

100. Cucari, N.; Esposito De Falco, S.; Orlando, B. Diversity of Board of Directors and Environmental Social Governance: Evidence from Italian Listed Companies. Corp. Soc. Responsib. Environ. Manag. 2017, 25, 250-266. [CrossRef]

101. Hair, J.F.; Black, W.C.; Babin, B.J.; Anderson, R.E. Multivariate Data Analysis; Prentice Hall: Upper Saddle River, NJ, USA, 2009.

102. Hair, J.F.; Sarstedt, M.; Ringle, C.M.; Mena, J.A. An assessment of the use of partial least squares structural equation modeling in marketing research. J. Acad. Mark. Sci. 2012, 40, 414-433. [CrossRef]

103. Serafeim, G. Public Sentiment and the Price of Corporate Sustainability. Financ. Anal. J. 2020, 76, 26-46. [CrossRef] 
104. ICAO Renewable Energy for Aviation: Practical Applications To Achieve Carbon Reductions and Cost Savings. 2017. Available online: https://www.icao.int/environmental-protection/Documents/ICAO_UNDP_ GEF_RenewableEnergyGuidance.pdf (accessed on 1 June 2020).

105. Yan, W.; Cui, Z.; Álvarez Gil, M.J. Assessing the impact of environmental innovation in the airline industry: An empirical study of emerging market economies. Environ. Innov. Soc. Transit. 2016, 21, 80-94. [CrossRef]

106. Heshmati, A.; Kim, J. Efficiency and Competitiveness of International Airlines; Springer: Berlin/Heidelberg, Germany, 2016; ISBN 9789811010156.

107. International Air Transport Association (IATA). Fact Sheet: Industry Statistics; IATA: Montreal, QC, Canada, 2014.

108. Kacperczyk, A. With greater power comes greater responsibility? Takeover protection and corporate attention to stakeholders. Strateg. Manag. J. 2009, 30, 261-285.

109. Cucari, N. Qualitative comparative analysis in corporate governance research: A systematic literature review of applications. Corp. Gov. 2019, 19, 717-734. [CrossRef]

Publisher's Note: MDPI stays neutral with regard to jurisdictional claims in published maps and institutional affiliations.

(C) 2020 by the authors. Licensee MDPI, Basel, Switzerland. This article is an open access article distributed under the terms and conditions of the Creative Commons Attribution (CC BY) license (http://creativecommons.org/licenses/by/4.0/). 